\title{
O PENSAMENTO POLÍTICO DOS FILÓSOFOS MILÉSIOS
}

Patricio Tierno é professor do Departamento de Ciência Política da Universidade de São Paulo. http://dx.doi.org/10.1590/ 0102-363404/100

[...] o caminho do espírito é o da mediação e do rodeio [...] G. W. F. HeGeL

O pensamento filosófico e científico originado na Jônia durante o século VI a.C., região leste da antiga Grécia, foi desenvolvido por três nomes oriundos de uma cidade do sul de Ásia Menor, Mileto, lugar onde Thales, Anaximandro e Anaxímenes levaram a cabo sua práxis intelectual. Em tentativas algo forçadas, eles soem ser inseridos numa nova corrente teórica em formação e difusão, que se expandiu para o oeste, mesmo sem ter acometido uma concepção única de filosofia (Long, 1999, pp. 12-13; Barnes, 1987, pp. 11-12).

Em geral, conforme a argumentação que reconstruirei particularmente aqui, esses três pensadores associam-se com frequência ao que se conhece como escola milésia (Guthrie, 2004 [1962], pp. 53 e 54), ou são incluídos na mais ampla escola jônica (Mondolfo, 2002 [1952], pp. 10 e 11). Dado o caráter artificioso da catalogação por escolas, introduzida mais tarde pela antiga literatura de sucessões 
(Barnes, 1987, p. 10) ${ }^{1}$, os pensadores milésios podem ser bem mais compreendidos, pois assim o intuiu o talento especulativo de Jaeger, como um autêntico movimento espiritual (Jaeger, 1967, p. 155 e passim; também Long, 1999, pp. 1 e 2, este último ressaltando que Protágoras foi talvez o único exemplo de uma pessoalidade que batizou e deu sustento, alguns anos após a sua morte, a um movimento que, com propriedade, será chamado de tal).

Da situação abastada, fluida e relativamente livre das cidades jônias se depreende, numa atmosfera de florescimento técnico e especulativo, um primeiro movimento intelectual específico, o dos pensadores milésios, que se define por um tipo singular de explicação e por um lógos que pôde produzir a manifestação concreta de uma forma filosófica, qua científica, de racionalidade. Mas, além de uma racionalidade filosófico-científica, esse movimento entranhou uma incipiente forma reflexiva com um conteúdo político 364 conceitual. Em que grau, se for plausível essa hipótese interrogativa, configuraram um modo político de pensamento, isto é, referido a conceitos políticos ou, à inversa, uma filosofia política significada pelo vocabulário da phýsis e da linguagem grega da filosofia da natureza, é o que explorará minha argumentação.

A hipótese de interpretação que proponho chegará a ser convincente, entretanto, se a vertemos a uma forma simples e direta de interrogação: por que se pode afirmar que os intelectuais milésios constituíram, de modo fundamental e numa fase formativa da filosofia, um pensamento político? Constituíram-no, de acordo com a interpretação avançada, no plano da abstração e generalização dos con-

\footnotetext{
${ }^{1}$ Cornavaca, contra o filólogo W. Schadewaldt (que também considerou inapropriado falar em escolas antes da época de Platão e do período helenístico), aduz tanto a convergência temática quanto a relação sucessiva de mestre a discípulo como justificativas para aprovar o emprego do termo escola com os três filósofos milésios (Cornavaca, 2008, p. 27).
} 
ceitos; agora, quanto ao conteúdo, o pensamento filosófico foi político por suas raízes míticas e por suas implicações normativas e teórico-práticas. Entre esses dois polos (o das origens remotas e o dos desdobramentos implicados), os conceitos desempenharam e compuseram, envolvidos na razão grega, uma função mediadora e um vocabulário a serviço da manifestação indireta da racionalidade política ou, concentrando ambas as funções, as condições prévias e lógicas de sua produção. E, ao passo que se desvelavam o momento da gênese e o desenvolvimento dos conceitos políticos, assistia-se, em simultânea e assimétrica marcha, à formação e a transformações das comunidades aristocráticas da primeira pólis ou, traduzido a categorias equivalentes, à sequência das condições históricas e de possibilidade da produção do pensamento político racional.

No que tange aos conceitos e, ainda, aos conceitos políticos, a questão tem de ser revista nos próprios textos. Nesse sentido, a análise conceitual e a crítica textual são recursos a aproveitar na reconstrução de uma linguagem distante e alheia, que não é direta de por si, expressada pelos pensadores milésios. Mas, na verdade, tudo resultaria inútil se essa reconstrução não recuperasse, vindo em auxílio um esboço de interpretação deliberado, a gênese, a estrutura e as ideias de um modo de pensamento que nasce e se desenvolve nessa fase inicial da racionalidade filosófica. Um intento preliminar se vislumbra endereçando o olhar para aquele modo da transição, sorte de arquétipo do qual cabe inferir a decisiva passagem do mito ao lógos, a transmutação da explicação mitológica e a personificação antropomórfica em explicação científica e stricto sensu intelectual, que organiza a massa confusa de fenômenos e sensações mediante a inteligência, operação com a qual se postula uma ordem endógena e básica susceptível de ser compreendida e reproduzida pelo intelecto e pelo discurso. Mais do que uma revolução puramente intelectual, tratou-se antes de uma mudança de signo 
especular, porque respondeu, condensada na teoria, a uma grande transformação econômico-social, religiosa e cultural, política e profundamente histórica. Os autores a analisar, na ordem de suas intervenções dentro do bloco intelectual jônio, que fomentou o movimento milésio, são os já mencionados Thales, Anaximandro e Anaxímenes de Mileto, examinados com similar procedimento, a saber, levando em conta o vocabulário político a que deram significado e as restrições da respectiva base textual, em consonância com a natureza das fontes testemunhais e fragmentárias que a eles iluminam, vinculam-se e remetem.

\section{Thales}

Thales de Mileto, a quem se pode considerar fundador do movimento intelectual milésio e, por conseguinte, do pensamento pioneiro de tipo filosófico ${ }^{2}$, foi, por isso, o primeiro, segundo a curta constatação de Aristóteles, que propôs 366 uma substância essencial como princípio material constitutivo de que estão constituídas todas as coisas. A autoridade dessa declaração e, por extensão, a autoridade que se deriva da linha interpretativa inaugurada por Aristóteles, e continuada por Teofrasto, e a tradição doxográfica vêm ratificadas pela cautela que aquele expôs, com referência a Thales, ao admitir que estava se apoiando em fontes secundárias (légetai, Met. 984a2) ${ }^{3}$, isso somado ao crédito que lhe cabe em razão de sua indisputável proximidade temporal com respeito ao pensamento milésio. Por essas várias razões, deveria bastar copiar os parágrafos da Metafísica que dão sustento às contadas e reveladoras palavras atribuídas a Thales:

\footnotetext{
${ }^{2}$ Simplício confirma que Thales foi o primeiro a apresentar o estudo da natureza aos gregos (Simplicius, Aristotelis physicorum libros commentaria 23, 29-33, apud Barnes, 1987, p. 61; tb. apud Kirk, Raven e Schofield, 1985, p. 86).

${ }^{3}$ A esse respeito, ver também Barnes (1987, p. 63).
} 
Dos primeiros que filosofaram, a maioria pensou que os únicos princípios são de natureza material (en hýles): e é que aquilo do qual estão constituídas todas as coisas que são, e a partir do qual primeiramente se geram e no qual ultimamente se decompõem, permanecendo a entidade por mais que essa mude em suas qualidades, isso dizem que é o elemento, e isso o princípio (arkhén) das coisas que são, e daí que pensem que nada se gera nem se destrói, posto que tal natureza (phýseos) se conserva sempre, de igual forma que tampouco dizemos que Sócrates "se faz" em sentido absoluto quando se faz belo ou músico, nem que "se destrói” quando perde tais disposições, já que o sujeito, o mesmo Sócrates, permanece: do mesmo modo tampouco poderá <dizer-se a respeito de $>$ nenhuma outra coisa, pois sempre há alguma natureza, seja uma ou mais de uma, a partir da qual se gera o demais, conservando-se aquela.

No que se refere ao número e à espécie de tal princípio, não dizem todos o mesmo, mas que Thales, o introdutor desse tipo de filosofia, diz que é a água (daí que dissera também que a terra está sobre a água), tomando essa ideia possivelmente de que via que o alimento de todos os seres é úmido e que a partir disso se gera o quente mesmo e disso vive (pois aquilo a partir do qual se geram todas as coisas é o princípio de todas elas) - tomando, pois, tal ideia disso, e também de que as sementes de todas as coisas são de natureza úmida, e que a água é, por sua vez, o princípio da natureza das coisas úmidas.

Há, de resto, os que pensam que também os mais antigos, os que teologizaram pela primeira vez e muito antes da geração atual, tiveram uma ideia assim acerca da natureza: com efeito, fizeram progenitores de todas as coisas a Oceano e Tétis, e < disseram $>$ que os deuses juram pela água, chamada por eles "Estige" [(d)os poetas]. Ora, o 
mais antigo é o mais digno de estima e o mais digno de estima é, por sua vez, aquilo pelo qual se jura. Não obstante, não está nada claro se essa opinião acerca da natureza é, efetivamente, primitiva e antiga; em todo caso, de Thales se diz que se manifestou desse modo acerca da causa primeira. (Desde já, ninguém pretenderia colocar entre esses Hipão, dada a vulgaridade de seu pensamento.) (Met. 983b6-984a $5^{4}$ [DK 11 A 12]).

A passagem é, em sentido fundamental, ainda mais esclarecedora: o que consagra a afirmação de Thales é a inclinação grega, para dizê-lo com o comentário de Guthrie (2004, p. 63 e ss.), "para a generalização, descartando o individual e o acidental e destacando o universal e permanente" ${ }^{5}$. Essa inclinação, acrescente-se, foi característica da mudança de orientação introduzida na mentalidade grega e da que Thales se apropriou de modo 368 fulgurante e novo: a água $\left(\right.$ hýdor ${ }^{6}$, diria hoje a generalização, é o princípio essencial, causa material e primeira, do ser de todas as coisas. De modo parelho, a passagem em sua totalidade e a afirmação de Thales são reinterpre-

\footnotetext{
${ }^{4}$ Neste, como em outros textos originalmente em grego, a tradução foi levemente modificada por mim. Demais traduções também foram feitas por mim.

${ }^{5}$ Antes, não sem evitar o anacronismo próximo e distante, havia escrito algo parecido sobre a irrupção da figura de Thales: "O talento grego para a generalização, para a extração da lei universal a partir dos casos concretos, a 'forma' a partir da 'matéria' havia começado a causar seu efeito" (Guthrie, 2004, p. 62; as traduções do espanhol e do inglês são minhas). Seja como tenha sido, o gênio dos gregos aplicado tanto aos assuntos práticos quanto às questões teóricas põe-se em relevo nas diversas facetas da biografia de Thales: de família distinguida, educado pelos sacerdotes egípcios, sábio e científico, estadista prático e filósofo ideal e teórico, astrônomo e matemático ou geômetra, escritor modesto, fonte verídica ou inverossímil de toda classe de anedotas e descobertas. Sua pessoalidade permanece em grande medida nas sombras. Ver Guthrie (2004, pp. 54-62), Cornavaca (2008, pp. 29-32). Para as fontes textuais que proporcionam tal informação, ver Kirk, Raven e Schofield (1985, pp. 76-99). E, sem copiar os textos em grego, mas mantendo seu contexto original, ver Barnes (1987, pp. 61-70).

${ }^{6} \mathrm{Na}$ opinião de Cornavaca (2008, p. 35), hýdor é a única palavra atribuível realmente a Thales.
} 
tadas por Aristóteles, com terminologia própria, pertencente a uma idade filosófica mais madura. Guthrie acerta ao observar que nenhum jônio teria feito público seu pensamento apelando a termos tais como matéria (hýle), entidade (ou substância, ousía) e qualidade (ou atributo, páthos), elemento (stoikheion), sujeito (ou substrato, hypokeimenon) etc. Mesmo assim, há dois vocábulos intima e reciprocamente relacionados que merecem imediato exame, os quais, me aventuro a dizer, estavam já impostados nas palavras de Thales: phýsis e arkhé, a natureza como princípio e o princípio da natureza.

A natureza (phýsis) reflete a genuína dimensão social originária, acaso política e cosmológica, da cidade (pólis). A asseveração poderia resultar temerária, se não fosse por sua duplicidade difusa, pela simplificação dual da realidade que comporta. A retradução da linguagem de Thales para o vocabulário técnico da filosofia de Aristóteles (que teve, vale aclarar, seu ponto de partida na análise lógica promovida por Platão) debela a busca encarada pelos filósofos da natureza milésios, e sobretudo por Thales, de um substrato subjacente, de uma substância e matéria que é desde sempre e que persiste através da mudança. A substância persistente a despeito das mudanças qualitativas, a identidade comum que se mantém no devir histórico, no ciclo das batalhas e das noites, essa é, concretamente, a exigência da comunidade humana. Essa exigência de vida biológica e vida grupal se aproxima, com um semblante físico, a um princípio universal de unidade, do qual, como caracterizou Mondolfo (2002, p. 10), “derivam todas as coisas, do qual constam, ao qual retornam, mantendo sempre esse princípio permanente e imutável através do aparecer, mudar e desaparecer de todas as coisas singulares". A cidade lateja nas primeiras e primitivas formas de agrupamento entre os homens dos tempos remotos, anteriores à escuridão rudimentar das invasões, nos laços primigênios 
das formas de existência tribal e aldeã que resistiram, com sua dispersão fragmentadora, à atração centralizadora dos palácios e das fortalezas.

A natureza equipara-se, pois, ao instinto gregário de sobrevivência e reprodução da comunidade. Ao mesmo tempo, o princípio (arkhê) não ignora a recomposição do fundamento comunitário e divino da cidade (pólis). A intervenção de Thales veio injetar no mundo natural e humano a ordem, a unidade, sentida como necessidade material e espiritual fazia já tempo. Estava em sintonia com as explicações religiosas das origens, não menos que com a propensão psicológica para a totalidade, para a falta em ser da plenitude, que implicava a superação do caos primordial por agentes divinos de forma humana. Claramente, esse instinto gregário e unitário devia ser, para certa concepção da existência coletiva não acostumada a deter-se nas aporias do pensamento, argui Mondolfo (2002, p. 10), o mais reduzido e extremo:

Esta concepção representa a tentativa racional de unificar e explicar a infinita multiplicidade e variabilidade das coisas testemunhadas pela experiência, por meio da unidade e permanência de um ser que as reúna todas nele, como fonte e causa do seu devir, e que justamente é buscado entre os seres da natureza fluente e dinâmica [...].

A cidade povoa a multiplicidade das formas sociais e naturais e, na sua crescente complexidade e copiosa evolução, enfrenta as tensões e conflitos que poderes e daímones suscitam e que a obrigam a incorporá-los ou a expulsá-los dela mesma.

A causa natural originária e o fundamento unitário fundem-se na afirmação de Thales, interpretada por Guthrie:

Todas as coisas foram uma vez água (se essa é a arkhê) e, para o filósofo, todas as coisas continuam sendo água, 
porque, apesar das mudanças que tenham sofrido, permanece a mesma substância (arkhé ou phýsis, princípio ou constituição permanente) através de todas elas, uma vez que realmente não existe outra coisa (Guthrie, 2004, p. 66; grifos no original) ${ }^{7}$.

O que interessava era a totalidade da phýsis, posto que tudo era em essência a mesma coisa e possuía a mesma constituição. Mas, a partir de Thales, tornou-se possível ver cada aspecto da natureza separadamente, trazendo ao pensamento (político) milésio (e, por que não dizer, a nós, seus herdeiros ocidentais) um ganho inestimável, uma reversibilidade que as entrelinhas de Raaflaud (2007, p. 49) enunciam sem percebê-lo completamente:

A física, a ética, a política e a religião não estavam ainda separadas em disciplinas especiais. O homem era parte da natureza, sujeito às suas leis; inversamente, os processos naturais podiam ser entendidos e explicados aplicando relações e regras observadas na sociedade humana.

Esse alto grau de conhecimento científico e especulativo, que possibilitou a conceituação teórica consciente de uma totalidade reversível em virtude de seu princípio material constitutivo, não poderia ter surgido se não tivesse integrado a problemática humana em um modo de pensamento que brotava do mito e se erigia em razão natural e política ${ }^{8}$.

\footnotetext{
${ }^{7}$ Para uma leitura divergente dessa passagem, em chave cosmogônica antes do que cosmológica, acrescentando que a fonte de Aristóteles foi, com probabilidade, o trabalho de Hípias que agrupava as opiniões dos filósofos e os poetas de acordo com sua similitude, ver Algra (1999, pp. 49-52).

${ }^{8}$ Naquele mundo heleno do século VI a.C., a filosofia científica e racional não teria sido possível em outro tempo e lugar que não reunisse as condições geográficas, geopolíticas e culturais para a proeminência das poleis jônias e de Mileto, garantias de seu intercâmbio colonizador e comercial e de seu papel intermediador
} 
A meio caminho entre essas duas subjetividades, do mito divino à racionalização do mito pela natureza e a política, Thales formulou sua hipótese à expensa de uma razão que, com ele, manifestava a racionalidade filosófica, o acabado modo da filosofia natural ou, seu valor equivalente, o da naturalização da razão. Essa e não outra foi a verdadeira e única fundação, a introdução de um novo tipo de "filosofia", ao menos no campo virgem dos conceitos teóricos, das nítidas aproximações reflexivas e intelectuais. Nessa perspectiva, é necessário perguntar por que Thales escolheu a água como princípio, causa e substância material. Por uma parte, Guthrie (2004, pp. 67-69) especifica os pressupostos míticos e as influências orientais desse pensamento, que mostram que o filósofo estava familiarizado com as ideias babilônicas e egípcias ${ }^{9}$. Tanto a Mesopotâmia como o Egito eram civilizações de rio, e o fato de ser a substância água essencial para a vida e a 372 produção de alimento, esta implantou-se na sua mitologia com suma facilidade. Não somente aduz Guthrie que personificações da cosmogonia babilônica e os conhecimentos dos sacerdotes egípcios (e, de igual maneira, pares de histórias dos povos do Oriente Próximo, como as dos hebreus) encontram paralelos na mitologia grega ${ }^{10}$, mas

e recebedor das correntes de influências práticas e teóricas, empíricas e ideológicas, circulantes entre o Mediterrâneo ocidental e as regiões do Mar Negro, o Levante, Anatólia, a Mesopotâmia e Egito. O posto de destaque das cidades jônias se conservaria como tal até 494 a.C., ano em que teve lugar o desastroso fracasso da sua revolta contra a Pérsia (Raaflaud, 2007, p. 48).

${ }_{9}$ Aécio (I, 3, 1) e Proclo (Euclidem, p. 65 Friedl. [DK 11 A 11]) noticiam a visita de Thales ao Egito (Kirk, Raven e Schofield, 1985, p. 79); Plutarco (Is. et Os. 34 [DK A 11], apud Guthrie, 2004, p. 67) supôs, ademais, que haveria sido ali que Thales, e também Homero, aprenderam que a água é o princípio de todas as coisas. Um escólio a Platão (República, 600a) diz que Thales "foi educado no Egito pelos sacerdotes" (apud Cornavaca, 2008, p. 30 [DK 11 A 3]), e Jâmblico (Vida de Pitágoras, 12) conta que Thales exortou Pitágoras a navegar para o Egito "e consultar em Mênfis e Dióspolis os sacerdotes" (apud Cornavaca, 2008, p. 30).

${ }^{10}$ Por exemplo, a cosmogonia babilônica do Enuma Elish (T. Jacobsen, Before philosophy, apud Guthrie, 2004, p. 68). De maneira extensiva, na esfera das ideias 
também Aristóteles, na passagem supracitada (Met. 983b6 e ss.), recupera os nomes míticos de Oceano e Tétis, pai e mãe de todos os deuses, menção que seguramente procede da Ilíada, XIV, 201 e 246 (tb. Il. XIV, 200; XVIII, 399; XXI, 196; e, para o juramento pelas águas do Estige, II, 755 e XIV, 271). (Homero, por certo, não cultivou a cosmogonia, porém essas remissões aos princípios masculino e feminino da água deveriam ser marcas sugestivas da incidência das genealogias orientais.)

Por outra parte, prossegue Guthrie (2004, pp. 69 e 70), podem ter sido igualmente a observação empírica ${ }^{11}$ e a procura de uma explicação racional as que induziram Thales a reparar na água como fonte e dispensadora de vida, visto que o calor e a umidade são propriedades do alimento e do sêmen. E Aristóteles, de acordo com a linha de pensamento que imputa àquele, parece ter tido presente os versáteis usos de hygrós (úmido, leve, flexível, inclusive aplicado a um arco, a Eros, aos membros do corpo, às costas de uma águia: apud Guthrie, 2004, p. 70) na língua grega, os quais permitiram confirmar que a noção de calor úmido, extraída dos saberes de Oriente e da experiência prática, dirigiu de tal modo o pensamento de Thales que o conduziu à potente associação da água com a matéria que constitui o primeiro princípio, o substrato elementar e essencial do mundo natural e social.

A interpretação (e sua implicação política) harmoniza com a evidência textual que se possui de Thales. Aristóteles

egípcias, a ordem humana, livrada a sua sorte, era incapaz de manter por si só a justiça e a solidariedade que, dispensadas e protegidas pelo faraó, assentavam-se na ordem divina (H. W. F. Saggs, Civilizations before Greece and Rome, New Haven, 1989, apud Raaflaud, 2007, pp. 52-53).

${ }^{11}$ Mas não a observação moderna de que a água muda de estado conforme as variações de temperatura. Pelo mesmo motivo, descarta-se a possibilidade de que Aristóteles tenha-se confundido e posto em palavras de Thales o que havia sido, em realidade, afirmado pela ideia, considerada vulgar ou superficial, de Hipão (s. V a.C.), a saber, que a alma é água (Met. 984a3, e De Anima, 405b2, apud Guthrie, 2004). 
adjudica-lhe a identificação da vida ou alma (psykhê) com a causa do movimento: "Também Thales, a julgar pelo que sabemos sobre ele, parece ter sustentado que a alma é uma força motriz, posto ter ele dito que o ímã tem uma alma porque faz mover ao ferro" (De An. 405a19-21; e Guthrie, 2004, pp. 73-74). Mais adiante, escreve: "E alguns pensadores dizem que a alma está mesclada no Universo todo, quiçá por isso também pensou Thales que tudo está cheio de deuses" (411a7-8 [DK 11 A 22] $)^{12}$. Nesses extratos se combinam duas crenças arraigadas: a primeira é a ideia tipicamente grega de que a natureza da psykhé comporta sua capacidade de movimento; e a segunda, uma concepção animista, que não podia ser desconhecida no repertório interior do universo mental grego. O exame das testemunhas sobre Thales, como ocorre com os demais pensadores milésios, exibe quase inexoravelmente uma afinidade comenta Guthrie sem se aprofundar demasiadamente nessa

374 observação - entre a visão helena do mundo e da vida, o que se poderia chamar de sistema convencional de crenças e valores correntes, e as práticas religiosas e políticas quotidianas. O que havia de novo e diferente, e que representou a contribuição original de Thales, radicava na múltipla integração com que esse pensador milésio acoplou essas crenças correntes e comuns às suas suposições e especulações acerca do mundo e da vida em uma teoria filosófica, uma história teórica, racionalmente unificada ${ }^{13}$.

A par dessa reconstrução do pensamento (político) de Thales, arriba-se a uma síntese certeira, que Guthrie, encerrando a análise do autor, define com prudente precisão:

\footnotetext{
${ }^{12}$ Platão, em Leis, 899b, parafraseia o mesmo apotegma, sem atribuí-lo concretamente a nenhum autor (Guthrie, 2004, p. 73). Testemunhas conexas que fazem alusão ao animismo de Thales localizam-se em DK 11 A 3, Cícero (Da natureza dos deuses, I, 25) e Aécio (I, 7, 11), apud Cornavaca, 2008, p. 37).

${ }^{13} \mathrm{~A}$ doxografia prova, inclusive, que Thales aderiu à indistinção entre animado e inanimado de forma mais consciente do que inconsciente (Diogenes Laertius, I, 24, apud Guthrie, 2004, p. 74 [DK 11 A 1]).
} 
Na medida em que podemos recompor o pensamento de Thales, partindo de nossas exíguas testemunhas, ele chegou à afirmação, em primeiro lugar, de que o mundo constava de uma só e única substância. Para ser a arkhé do mundo, essa substância tinha de conter em si mesma a causa do movimento e da mudança (isto, admitamos, não necessitaria argumentação, tratar-se-ia de uma suposição), o que para um grego significava que havia de ter natureza de psykhé, vida ou elemento animado. Thales pensou que a água era a substância que mais bem cumpria esse requisito ou, de modo mais geral, o elemento úmido (tó hygrón [...]). Esta era, pois, a arkhé e, como tal, era viva e imperecedoura (Guthrie, 2004, p. 75).

A filosofia natural de Thales, caberia então concluir, entranha uma inseparável dimensão humana e, conseguintemente política, que reabsorve no interior de uma substância essencial a dinâmica do todo e a organização da vida física e metafísica que receberá, como se verá aqui adiante, maior e mais clara significação com Anaximandro. É tão forte a impressão causada por isso, que custa entender por que nunca teria sido reconstituído pela hermenêutica especializada, que praticamente se entregou ou à costumeira história da filosofia ou ao isolamento não filosófico da reflexão político-poética. Demasiadas vezes passou-se por alto que a filosofia política espreitava nos interstícios do nascente pensamento racional e era, secreta e complexamente, seu combustível intelectual e histórico. Em um primeiro e significativo movimento, com e por Thales, o pensamento político e social milésio desviou-se da imagem grega do divino (tó theíon). Desterrando as formas antropomórficas da religião mítica e popular, Thales recriou a linguagem religiosa e mitológica dos deuses e poderes especiais, naturalizando-os, isto é, conceituando-os na natureza como mudanças de uma substância constitutiva que se acha na natureza das coisas mesmas. A natureza 
viu-se, a partir de então, como uma totalidade unitária, que tudo compreende, explica e torna explicável em razão de um princípio essencial animado.

Contudo, e num segundo instante, essa integração completa da phýsis fez que Thales repensasse, de modo absolutamente distinto, a dinâmica da divisão. Um pressuposto das cosmogonias e teogonias, compartilhado com os mitos do Oriente que falavam de um ato de criação, determinava que no princípio tudo estava misturado numa massa indiferenciada e que tudo começava, assim, com esse ato inicial de separação (Guthrie, 2004, pp. 76 e 77; Kirk, Raven e Schofield, 1985, pp. 9-71): Hesíodo, e o engendrado abraço entre Gaia e Urano, que se multiplica em progênies e procriações secundárias (Theog. 116 e ss.); a tradição atribuída a Orfeu, de que a Terra e o Céu saem da produção de um ovo; ou as doutrinas de Museu e de Epimênides, discípulos do anterior, nas quais se combinavam a origem, a composi-

376 ção e o consumo ou resolução de todas as coisas na mesma coisa. Da separação mítica, a seu modo racional e, segundo a visão convencional de muitos intérpretes e comentadores, pré-filosófica, apropriou-se Thales, que a reconfigurou sob os moldes de um monismo naturalista, balizando a trilha que percorreriam os outros pensadores milésios, com base na qual se poderia pensar a variedade da natureza nos exclusivos termos da natureza em si e para si, una e diferenciada. Julgo que o mérito de Thales é superior ao pouco que sabemos realmente dele: naturalização do mito, racionalização da natureza - elaboração de um pensamento filosófico e científico, teórico e histórico, da substância e da matéria, e racional em sentido estrito. Uma racionalidade política qua filosófica que, encarnada numa pessoalidade e numa fase formadora da razão grega, expressou a unidade teórica da ordem, a divisão conceitual da unidade, forjando uma visão que, diferentemente das cosmogonias de deuses que se uniam e separavam em progressões sexuais, demandou 
a seus contemporâneos, sem ainda ser crítica de seus limites helenos, uma eterna pergunta, uma única e constante explicação.

\section{Anaximandro}

Anaximandro, que teve algum vínculo com Thales, é visto pela posteridade como puro físico (" a full-blooded physikos" [Barnes, 1987, p. 36]). Trata-se, quiçá, do primeiro grego que deu publicidade a um tratado, escrito na novel forma da prosa, dedicado a investigar a natureza ${ }^{14}$. Na chave de interpretação que desvenda este ensaio, ele foi provável participante, enquanto continuador necessário e fundamental, com referência ao bloco intelectual jônico, do especificamente delimitado movimento dos pensadores milésios. Dentro dessa compreensão, o texto central nos é proporcionado pelo fragmento ímpar que se lhe imputa,

\footnotetext{
${ }^{14}$ Um pouco mais jovem, aluno e amigo, colega e concidadão de Thales, Anaximandro escreveu um livro que, já na Antiguidade, recebeu o mesmo título que era usado para os escritos dos habitualmente denominados pré-socráticos: Sobre a natureza (perí fýseos). O Suda, léxico bizantino do ano 1000 d. C., registra mais de cinco títulos, possíveis capítulos ou divisões da obra principal do filósofo. A temática coberta era tão vasta como o universo que indagava: partia da geografia (o que aproxima Anaximandro de outro milésio, Hecateu) para compor uma incrível história universal que arrancava no momento da formação do Cosmos, passava por sua ordenação astronômica e culminava numa descrição da terra habitada do modo em que chegou a ser e era naquele presente. De haver sido assim, raciocina Guthrie, a cosmologia de Anaximandro teria tido, de fato, mais desenvolvimento que sua cosmogonia, que foi preparatória e preliminar; não obstante, coincidente com a doxografia que se fundara nos interesses histórico-intelectuais de Aristóteles e Teofrasto, Guthrie termina optando por um mais razoável respeito do que dizem as fontes peripatéticas antigas. O curioso é que nem Anaximandro nem Anaxímenes haviam sido nominalmente citados antes de Aristóteles. Essa omissão, que inclui não sem surpresa Platão, levou a que O. Gigon supusesse que Aristóteles, ávido de saber, achou cópias das obras e as preservou na biblioteca do Liceu. A suposição é sagaz e extraordinária e reinstala a linha interpretativa de Aristóteles e Teofrasto num lugar preferencial. Para os dados cronológicos, os escritos e os interesses de Anaximandro, v. e cf. Guthrie, 2004, pp. 79-83; tb. Cornavaca, 2008, pp. 39 e 40; para algumas das fontes doxográficas que subsidiam este resumo intelectual e biográfico, ver DK 12 A 1, 2, 6 e 11; tb. Kirk, Raven e Schofield, 1985, pp. 112-163 (com os textos, em grego e traduzidos, distribuídos em seções que classificam a vida, a doutrina e os fragmentos e paráfrases subsistentes); e Barnes, 1987, pp. $71-76$ (com menos testemunhas e o formato editorial explicado supra).
} 
de relevante vocabulário ético e político, e ao que Simplício acessou através do Opiniões dos físicos (Physikón dóxai) de Teofrasto:

Anaximandro [...] tem dito que princípio (arkhén) e elemento (stoikheion) dos seres é o ilimitado (tó ápeiron), sendo ele o primeiro a introduzir esse nome de "princípio". E diz que não é água nem algum outro dos que se chamam elementos, mas outra natureza ilimitada (phýsin ápeiron), da qual se produzem todos os céus (ouranoús) e os mundos [kósmou] [que há] neles, desde o qual (ex hón) há geração para as coisas que são e para isso se produz a corrupção, segundo o que deve ser (katá tó khreón); com efeito, elas expiam (diken) e reparam (tísin) a injustiça (adikias) reciprocamente, segundo a ordenação (táxin) do tempo, dizendo assim essas coisas com nomes bastante poéticos. É claro que quando ele observou como os quatro elementos se transformam uns nos outros, não acreditou ser razoável pensar que um deles subjazia nos restantes, por isso postulou algo à parte. Ademais, ele não explica a gênese (génesin) mediante uma alteração qualitativa do elemento, senão mediante uma separação (apokrinoménon) dos contrários, originada pelo movimento eterno (Simplicius, Aristotelis physicorum libros commentaria $24,13-25^{15}\left[\right.$ DK 12 A 9 e B 1] ${ }^{16}$ ).

Esse longo excerto, alusivo, e com proposições subordinadas equívocas, é susceptível, no entanto, de uma série de elucidações linguísticas. O primeiro parágrafo, onde se encontra o fragmento 1 (que usualmente começa em ex hón e pode chegar até táxin ou o final da frase), enuncia o ilimitado ou, em diferentes

\footnotetext{
${ }_{15}$ Ver Simplicius, Aristotelis physicorum libros octo commentaria, 2 v. Ed. Diels, H. Berlin: Reimer, 9: 1882; 10: 1895; Commentaria in Aristotelem Graeca 9 \& 10, vol. 1, p. 1, line 1T (Thesaurus).

${ }^{16}$ Para uma comparação das versões do fragmento de Teofrasto e a substância originária, ver Hipólito (Refutatio onmium haeresium, I, 6, 1-2 [DK 12 A 11]), Pseudo-Plutarco (Stromateis, 2 [DK 12 A 10]) e Kirk, Raven e Schofield (1985, pp. 106-108).
} 
e particulares sentidos, infinito e indeterminado (como se verá a seguir), como elemento (o termo aristotélico stoikheion) e princípio (arkhé, cujo uso é adjudicado a Anaximandro) (ver tb. Simplicius, Aristotelis physicorum libros commentaria, 150, 22). Logo, no segundo trecho que segue ao fragmento 1, Anaximandro elucubra que, detrás dos elementos visíveis (a água ou qualquer dos outros ingredientes da matéria chamados elementos na Antiguidade), existe uma substância indefinida e imperceptível, natureza material originária e primitiva do Universo em seu conjunto, na qual estão os contrários que se manifestarão nas mudanças secundárias, surgidos a partir de uma separação primária (tb. [Aristóteles] Phys. 187a20-21).

Na época, os elementos (terra, água, ar e fogo) ofereceram a evidência comprovada do conflito entre contrários e as conversões entre opostos na natureza ${ }^{17}$. Repete-se a terminologia aristotélica que permeia as paráfrases de todos esses filósofos, a qual pode dissimular a falta da distinção, explorada logicamente por Platão e consolidada pela sutileza categorial de Aristóteles, entre a substância e o atributo, entre um sujeito e a qualidade que se pode predicar (porque está ou se diz) dele. Por essa razão, deve ser antecipado (Guthrie, 2004, p. 86, que se apoia numa anotação de F. M. Conford; e tb. pp. 85-89) que os pensadores milésios apelavam a uma linguagem ainda amarrada às suas figurações arcaicas: os contrários naturais denotavam-se com um artigo e um adjetivo de modo que o quente, o frio, o úmido e o seco eram coisas substantivas, tal como o seria o ilimitado

\footnotetext{
${ }^{17}$ Entre os gregos, a possível conversão ou, melhor dizendo, a origem do fogo a partir da água e a umidade respondia à crença na alimentação do Sol e do Cosmos, por meio de exalações do elemento nutritivo (e, é claro, de sua inseparável propriedade substantiva), necessário para qualquer forma de vida. A crença exprime, na inteligente e profunda apreciação de Guthrie (2004, pp. 74, 75, 87), "o pensamento de homens para os quais todo o Universo é um organismo vivo”. A visão orgânica se fará patente com Anaximandro, como se verá adiante. É importante lembrar, ademais, que a teoria dos elementos ou corpos simples só seria formulada de modo consciente por Empédocles no século V a.C., para depois ser incorporada e modificada por Aristóteles em sua explicação da mudança.
} 
(tó ápeiron) na mente de Anaximandro. Essa coisificação da qualidade, esse adjetivo em substantivo, foi o condicionante da observação fática da tendência de um oposto de destruir o seu contrário. No limite da linguagem, Anaximandro teceu com brilhantismo duas hipóteses relacionadas: primeira, a necessária simultaneidade de todos os elementos do mundo físico; e, segunda, a impossibilidade, desde a origem e para sempre, de que um deles predominasse ou se impusesse permanentemente sobre os outros. Ao descartar um dos opostos como arkhé originária e subsistente, verbi gratia a água, que Thales havia racionalizado, transportado pelos mitos orientais, com rapidez meditada, Anaximandro obrigou-se a uma terceira hipótese explicativa (Phys. 204b24 e ss. $\left.{ }^{18}\right)$ : a existência primária de uma substância prévia e indiferenciada, "da qual" geram-se a pluralidade dos céus e os mundos ${ }^{19}$, e "desde o qual" ${ }^{20}$ se explica, em conformidade com o necessário ("o que deve ser”), o ser e perecer 380 (a "geração" e a "corrupção") das coisas que, por meio dos contrários elementares, dão-se justa compensação (ou retribuição, como por vezes é também traduzido) pelas injustiças que se cometem na ordem do Universo presente, sucessivo e equilibrado dos dias e das noites e das estações do tempo.

\footnotetext{
${ }^{18}$ Passagem da Física na qual Aristóteles não cita, por seu nome, Anaximandro.

${ }^{19}$ Sobre a tese de Anaximandro dos mundos inumeráveis, seja interpretada como sucessão temporal de mundos, seja lida na coordenada espacial de uma multidão coexistente de mundos, controvérsia que se aclara alistando os diferentes sentidos discriminados na época clássica de kósmos e ouranós, recomenda-se o minucioso exame crítico de Guthrie (2004, pp. 111-18).

${ }^{20}$ Sobre o problema do fragmento de Anaximandro no que toca ao antecedente do giro "desde o qual" (eks hón), cujo pronome relativo hón está, vale salientar, em genitivo plural e, por conseguinte, exigiria, ora um antecedente também em plural, que deveria ser "os céus" ou "os mundos", ou, como segunda possibilidade exegética e sintática, a consideração do ápeiron como pluralidade, e, portanto, mescla ou fusão de contrários contida no ilimitado (Cornavaca, 2008, p. 49). De todo modo, Guthrie, em franca discordância com vários intérpretes, não pensa que o segmento "há geração para as coisas que são e para isso se produz a corrupção, segundo o que deve ser" se refira à geração primária dos contrários a partir do ápeiron e sua posterior e final reabsorção nele (Guthrie, 2004, especialmente p. 87 e n. 68 , e tb. pp. 115-16).
} 
A criação inicial da ordem diferenciada do Cosmos provém, pois, de um princípio indiferenciado que origina a separação dos contrários. Diversas conotações resultam apropriadas para o termo ápeiron, suscitadas pelas acepções que Aristóteles enumerou em Phys. III, 4, e pelas intermináveis querelas filológicas. Parece suficiente deslindar duas acepções prováveis e entreveradas que, induzidas por Anaximandro, cobram relevo por sua densidade e opacidade políticas. De uma parte, remete-se a uma dimensão temporal, que se expressaria no próprio sentido do termo infinito. Esse primeiro sentido tem afinidade inegável com a concepção religiosa e primitiva da imortalidade, que Anaximandro transladou a seu ápeiron, uma vez mais, em resumidos tons poéticos: "a natureza do ilimitado [...] é eterna e sem velhice" (Hipólito, Refutatio onmium haeresium, I, 6, 1, apud Cornavaca, 2008, pp. 50-51 [DK 12 B 2]; e Guthrie, 2004, pp. 89-90). Essas duas notas essenciais completam-se com o discorrer autorizado de Aristóteles:

[...] tudo é ou um princípio ou a partir de um princípio, mas do infinito [ilimitado] não há princípio porque haveria um limite disso. Ainda mais, é ingênito e indestrutível como princípio que é, pois o que se gera tem de alcançar necessariamente um fim e também há um fim de toda destruição. Pelo que, segundo vimos dizendo, eles pensam que não há um princípio deste princípio, mas que ele mesmo o é de todos os demais e que o abarca tudo e tudo governa, como afirmam quem não estabelece fora do infinito [ilimitado] outras causas como o Pensamento ou a Amizade; e pensam que isto é "o divino" (tó theion), pois é imortal e imperecedouro, como afirmam Anaximandro e a maioria dos filósofos da natureza (Phys. 203b6-14 [DK 12 B 3]).

A distinção traçada entre aqueles que idealizaram uma força motriz separada (o excerto reenvia, em todo caso, 
a Empédocles e Anaxágoras) e, pelo contrário, os que se permitiam acreditar numa matéria animada (os milésios), assume um sentido máxime com Anaximandro, para o qual a arkhé era origem e inclusão do ser de todas as coisas e, ao mesmo tempo, a força diretora delas (ilustrado pelo verbo kubernán, Phys. 203b12, literalmente "governar uma nave": Guthrie, 2004, pp. 93-94). Essa capacidade geradora, abarcadora e governadora do arkhé-ápeiron invita a vê-lo, verbalmente, como coisa divina. A conjugação dos dois últimos textos equivale a somar as notas essenciais do ápeiron divino: puro presente e sem idade, não engendrado, incorruptível, infinito na sua imortalidade e perdurabilidade ${ }^{21}$.

De outra parte, despeja-se uma dimensão conceitual, promovida pelo impacto visual de representar o ápeiron como uma massa enorme que abarca o mundo ou uma compreensiva esfera (periéxein, Phys. 203b12; e Guthrie, 2004, pp. 91-92). Por intermédio dessa representação, a 382 segunda acepção é convocada pela anterior. Em face de um pensamento que outorga às palavras um caráter de entidade, e que visualiza nos distintos significados de um termo apenas aspectos de uma única coisa significada singular, replica-se a reminiscência arcaica segundo a qual uma palavra ou nome possui uma existência separada e o significante é um significado inclusivo essencial. Do ponto de vista conceitual, então, ápeiron pôde ter assumido, por vontade de Anaximandro, o sentido de indeterminação (interna) de um corpo, isto é, de uma massa (circular) indiferenciada de elementos materiais entre os que não existem contornos definidos nem linhas divisórias de seus respectivos começo e fim.

E o indeterminado determina-se por separação (apókrisis), causada pelo movimento eterno no ápeiron. Tal movimento ${ }^{21}$ De novo, e sobretudo com Anaximandro, intui-se o Universo sob o prisma da
concepção de um organismo vivo. 
de separação origina a ordem do mundo desde a sua natureza primigênia, ativa em um princípio e como princípio, que é uma matriz divina, eterna, viva e automovida, da qual se depreenderá um germe de calor e frio, semelhante a uma semente, o núcleo capaz de engendrar, e cujo desenvolvimento embrionário dará lugar às diferenciações das ordens astronômica e terrestre (DK 12 A 10; Guthrie, 2004, pp. 95 e ss.; e tb. Cornavaca, 2008, pp. 40 e ss.). No que diz respeito à cosmogonia e à subsequente cosmologia de Anaximandro, creio razoável deter-se aqui. Prima neste recorte do lógos explicativo uma linguagem orgânica com a que se descreve a geração e reprodução da vida astral e, em última instância, animal e humana. Mais do que mera analogia biológica, a descrição e explicação da gênese faz real uma arkhé primária que, pela separação e ação constante dos contrários, dos opostos da e na natureza, leva em potência, para expressá-lo numa linguagem aristotélica, a ordem natural e social do mundo. Uma visão do mundo e da vida impregnada da abissal noção de organismos naturais férteis e criadores que descansa, após a conversão semântica que lhe é própria, no mais primitivo tema do ovo "teologizado" das variações órficas e das resenhadas, com Thales, cosmogonias da separação ${ }^{22}$.

O monismo orgânico de Anaximandro, repleto de contrário ou opostos, transcorre na totalidade do devir cósmico. Sua dinâmica secundária procede "segundo o que deve ser", katá tó khreón (DK 12 B 1, já citado) ${ }^{23}$, o decreto da necessidade, que é a legalidade universal da natureza inscrita nos conflitos dos elementos físicos, nas materializações normativas dos

\footnotetext{
${ }^{22}$ Para as cosmogonias órficas e o tema do ovo em fontes gregas não órficas, ver Kirk, Raven e Schofield (1985, especialmente pp. 21-33).

${ }^{23}$ Sobre a frase estruturada em torno de katá tó khreón, considerada significativa e que enlaçará com o que segue, consultar as diferentes traduções e hermenêuticas recenseadas por Cornavaca (2008, pp. 49-50). Para algumas opiniões sobre a extensão do fragmento 1 e a estrutura katá tó khreón como começo dele, ver Guthrie (2004, p. 83, n. 61).
} 
costumes e das leis. Essa legalidade comum, atinente às coisas dos homens e do mundo, efetiva-se como justiça, ou como seu reverso, a injustiça, que aquelas coisas mundanas "expiam e reparam [...] reciprocamente, segundo a ordenação do tempo" (DK 12 B 1). Enfrentado o fragmento 1 de Anaximandro, Balot (2006, p.20), ao acudir ao resgate do pensamento político grego na poesia, com alguma vaguidade, escreve:

A justiça foi uma preocupação central de diferentes classes de pensadores no período arcaico. A justiça foi um termo chave, por exemplo, na explicação física arcaica dos teóricos sobre a ordem e o balanço no Cosmos; ela podia consistir num equilíbrio entre "opostos" (Anaximandro [DK 12 B1]).

A justiça era, assim, um distintivo nítido da condição mundana:

Mas a justiça foi de maior interesse ainda para aqueles pensadores cuja preocupação primária era o mundo social e humano.

Não deixa de ser verdade que o labor pedagógico de Hesíodo em, por caso, Os trabalhos e os dias direcionou-se para o contraste entre os animais e os homens, marcado pela justiça, concedida por Zeus aos segundos e sancionada e administrada divinamente com base no respeito aos juramentos e às regras imparciais ( $W D, 202-285$, parcialmente também citado em Balot, 2006, p. 21). Mas a centralidade da justiça não se firmou nessa pura poética da exortação instrutiva.

Diferentemente, o propósito moralizador de Hesíodo prova que deve ser explorada uma conceituação mais densa e totalizadora, a de Anaximandro, que excedia o perceptível e a sentida preocupação com as ações dos injustos e poderosos, que teorizava sobre a justiça na ordem do mundo, sobre uma forma de expiação e reparação que regula o equilíbrio 
da organização dos homens. Um denso pensamento conceitual e uma conjunta racionalidade filosófica e política deslizam, dessa maneira, as principais características definidoras da pólis arcaica, as de uma comunidade política abarcada normativamente, ancorada num local de intercâmbio, de debate público, de compensação e retribuição através do rural, formada ao redor de uma identidade comunitária. Voltando às palavras do autor e fazendo jus às suas implicações, pode-se conferir de que modo se retira o velo que até agora ocultava uma lei comum, universal, que recobre o mundo como se fosse uma esfera, um todo circular, temporal e espacialmente ordenado, como se fosse, porque o era, uma cidade organizada.

Por essa via, retornam várias das continuidades e mudanças indicadas por Vernant ao se adentrar nas origens do pensamento grego, naqueles interstícios que as reconstruções mais atualizadas da teoria política clássica prescindiram de estudar (ver, para os seguintes parágrafos, Vernant, 1965, caps. VII e VIII). O acento posto em "o que deve ser", frase politicamente crucial de Anaximandro, encaixa-se em uma explicação genética que é, assim mesmo, uma explicação natural, teórica e histórica, que tem seu centro nas comunidades gregas antigas e, como diria Vernant referindo-se ao quadro geral da astronomia jônia, igualmente centrada e geométrica, tendo como centro do Universo a Terra $^{24}$. A phýsis estriba na génesis a partir de uma arkhé, de uma origem e começo temporal do mundo; a phýsis estriba, em não menor medida, na génesis da sua própria arkhé, da ordem, desenvolvimento e constituição material e espacial

\footnotetext{
${ }^{24}$ No concernente ao postulado da posição e permanência da Terra no centro do Universo afirmado por Anaximandro e, em geral, a sua cosmologia e disposição de "um Cosmos matematizado constituído por relações puramente geométricas", v. e cf. Vernant, 1965, esp. pp. 96-98 (cita da p. 97); mais ampla e imprecisamente, Guthrie, 2004, pp. 95-106; e, de maneira pontual, DK 12 A 11 e 26, testemunhas correspondentes a Hipólito, Refutatio onmium haeresium, I, 6, 3-7, e Aristóteles, De Caelo, 295b10 e ss. Não posso expandir essa cosmologia sem pagar o preço de deslocar o eixo da minha interpretação para muito além da teoria política.
} 
desse mesmo mundo. A natureza é total e incessante; tem invadido, sendo princípio da origem e princípio da constituição das coisas, a totalidade do ser, do existir, homogeneizando os planos temporais e espaciais outrora heterogêneos das teogonias e cosmogonias míticas e dramáticas.

A ordem cósmica e a organização humana que ajustam o pensamento filosófico-político milésio opõem-se, radicalmente, àquela hierarquia e às assimetrias que o mito aspirava legitimar. Seria oportuno transcrever o processo histórico e intelectual que se aprecia na insinuação de Vernant:

Secularização do saber, advento de um tipo de pensamento estranho à religião [...]. Na sua forma, a filosofia relacionase diretamente com o universo espiritual [...] que definia a ordem da cidade e caracterizava precisamente uma laicização, uma racionalização da vida social. Mas a dependência da filosofia com respeito às instituições da pólis acusa-se igualmente em seu conteúdo (Vernant, 1965, p. 86).

O decurso da pólis transcorreria nas antinomias conciliadoras da sua constituição, sua gênese, seu princípio: luta agonal das famílias e debate pela palavra, retração ritual do génos nobiliário e reinado do basileús aristocrático versus apertura pública dos atos políticos e da categoria social do hoplites e dos setores médios (oí mésoi), hýbris nas rivalidades entre géne tribais e medida (ou moderação, sophrosýne) e semelhança (ou similaridade, homoíoma), para os de igual condição (isótes), na união harmônica da philía cidadã . Entre a ressonância protoarcaica da mitologia política e a emergência pós-arcaica da filosofia política, instalada no meio, no centro (en méso; es méson), no lar (hestía) e praça (agorá) mercantis e comuns, situa-se a cidade e sua organização de justiça ${ }^{25}$. Num extremo

\footnotetext{
${ }^{25}$ Sobre os significados da hestía koinée da agorá, cf. tb. Vernant, 2006 (1965), pp. 157-96 e 197-211. Uma síntese e um esquema explicativo e reconstrutivo da gênese da pólis e da democracia ateniense têm sido expostos por mim: ver Tierno (2014).
} 
ideológico, o mito político de uma soberania ultrapassada, a de um deus, Zeus, que instituiu sua monarkhía absoluta e dominou a ordem do mundo, traz sua vitória sobre gerações de deuses e potências naturais sacralizadas.

No outro polo da ideologia, a filosofia política da natureza de poderes (físicos) que se igualam, que não se rendem à dominação de um exclusivo e supremo krátos supraelevado. Anaximandro assimilou a mediação com lucidez: se um dos elementos possuísse a arkhé que só o ápeiron pode equilibrar, estaria em condições de triunfar sobre os demais elementos e submetê-los indefinidamente, abolindo a garantia de estabilidade e persistência de uma ordem igualitária do mundo, onde as forças (naturais) profanas são regidas por relações de justiça recíproca (retributiva ou compensatória) sob o império de uma lei comum (de novo, Aristóteles, Phys. 204b24 e ss., já citada).

A igualdade (isonomía), filha da virtude naturalizada e politizada da justiça $(d i k e)^{26}$. Um nexo de filiação mais tímido e intangível que demorou a aparecer e que requereu que uma conceituação e uma racionalidade filosófica e política, a de Anaximandro, promovesse sua aparição como nunca antes. Anota, algo mais incisivo, Raaflaud (2007, p. 49):

O Cosmos é aqui [no fragmento B1 de Anaximandro] conceituado como um sistema sujeito às leis e às relações de justiça. No ilimitado ápeiron, todo ser potencial existe em perfeita mescla e balanço dinâmico. As coisas que existem emergem a partir dele num balanço dos opostos. Tal balanço representa a justiça, a dominação de um sobre o(s) outro(s), injustiça, a qual deve ser compensada no curso do tempo. Essa visão do Cosmos pressupõe um conceito análogo da ordem política e social: funciona somente na base da justiça e do balanço de poder entre iguais (isto é, isonomía [...])

${ }^{26}$ Sobre sua etimologia arcaica, ver Guthrie (2000, pp. 12-15). 
Essa reinterpretação do pensamento político grego, ainda que mais bem dirigida, não extrai todas as consequências possíveis da filosofia política de Anaximandro. $\mathrm{O}$ equilíbrio de poderes (noção que, de um modo ou outro, estará destinada a fazer história na teoria e nas ideias institucionais e políticas modernas) é, de fato, dinâmico e antitético e, além do mais, constitutivamente conflituoso. E, nesse contexto, o equilíbrio conflituoso caracteriza um poder contrário, posicional e igualitário; no Universo como no mundo propriamente humano, o poder de dominação permanente sobre os outros é negado ${ }^{27}$, o krátos é sempre um exercício simétrico, alternado, de substituições, realizado por turnos através de uma supremacia transitória, que vai passando de um elemento, ator ou estado, para outro, em ordenação regular e sucessiva. O ápeiron converte-se, mostra Vernant, no germe da ideia democrática: "Constituído por dynameis [potências] opostas e incessantemente em conflito, o mun388 do submete-as a uma regra de justiça compensatória, a uma ordem que mantém nelas uma exata isotés" (Vernant, 1965, p. 100). É essa a dike que define a igualdade de condições, sem especificar ainda quais serão os lugares sociais (os sujeitos coletivos) dessa igual condição. Mas a reflexão de Anaximandro já era política e ilimitadamente democrática porque a justiça e a indeterminação democrática habitavam a pólis histórica e tomaram como lugar de confronto o centro de debate discursivo e intelectual.

É sabido, graças a Vlastos, que a justiça igualitária de Anaximandro encontra acolhida no pensamento médico do século V a.C. (Alcmeão e escritos hipocráticos) e se vê confirmada, quando não no seu conteúdo, no mínimo na sua forma, por posteriores representantes da filosofia monista e pluralista (Heráclito, Parmênides e Empédocles) [Vlastos,

\footnotetext{
${ }^{27}$ A expressão hypó medenós kratouménen, na qual intervém a noção de krátos, pode ter pertencido a Anaximandro. Ver DK 12 A 11 e Vernant, 2006, pp. 213-33.
} 
$1970]^{28}$. Não tão distinto acaba sendo quando se observam, em retrospecto, os reformadores arcaicos (sábios, magos, tiranos e legisladores) que, com o despontar do século VII a.C., mediaram nos conflitos da cidade suscitados entre a aristocracia rica, os camponeses médios e os despossuídos e economicamente oprimidos, possibilitando a combinação do ideal da boa ordem política, a eunomía, com a isonomía, a igualdade por lei e a igual participação nos assuntos comuns (mais tarde tornada, também, isegoría, igualdade de palavra ou discurso). Sem embargo, essa igualdade política ainda estava confinada à aristocracia e sua lei da medida proporcional, que visava à integração e à harmonia na associação entre diferentes, de acordo com a condição (natureza) e posição desiguais (status e mérito) dos homens e das coisas (Raaflaud, 2007, pp. 42-48; Vlastos, 1970, pp. 56 e 57) ${ }^{29}$. Mas foi o pensamento natural (político) milésio que elevou a um plano abstrato e teórico a evolução, no momento incompleta, que conheceria o cidadão-soldado e a constituição da cidade ao avançar o século VIII a.C., com a grande Retra do legendário Licurgo (que evoca a redefinição dos cidadãos espartanos como hómoioi) e, no final do século VI a.C., com as reformas territoriais de Clístenes e a instauração da plena democracia (os atenienses, nessa ocasião, redefinidos como cidadãos iguais [ison] $)^{30}$. Nesse trajeto de formação da igualdade democrática, devem

\footnotetext{
${ }_{28}$ A rigor, a palavra isonomía não forma parte do vocabulário de Anaximandro; ver Vlastos (1953, especialmente pp. 361 e ss.).

${ }^{29}$ Desse modo proporcional, racional e conservador, idealizou e implementou a díke Sólon na sua obra poética e política em Atenas (Vlastos, 1946). A rotação e duração limitada das magistraturas foi precocemente prevista na figura dos kósmoi cretenses; ver Raaflaud (2007, pp. 44-45). Fazendo referência à eunomía e sua elaboração pela tradição poética e a intervenção dos legisladores, o mesmo Raaflaud (2007, p. 46) explica: "O ideal da eunomía [...] manteve-se não somente para a boa ordem social, mas também para a resolução política da crise e da stasis e pela integração da pólis". Para os primeiros sábios e a reflexão política e moral dos legisladores, ver Vernant (1965, cap. V).

${ }^{30}$ Para continuar com a análise espacial da perspectiva das reformas institucionais de Clístenes, ver Vernant (2006, pp. 235-59).
} 
ponderar-se, com sumo cuidado e mais uma vez, os fluxos do intercâmbio cultural durante a fase orientalizante do período geométrico (séculos VIII e VII a.C.), que aproxima e contrasta a evolução sequencial da Grécia arcaica com a organização em grande escala do Egito e o sistema de cidades em Anatólia, a Mesopotâmia, o Levante ou, também, o interessante exemplo das cidades fenícias. O que diferencia decisivamente os gregos dos povos do Próximo Oriente é uma incomparável acumulação e o sentido democrático das transformações sócio-históricas por eles experimentadas, as quais redundaram, em razão da sua complexidade evolutiva, na gestação de toda uma estrutura social, política e religiosa inteiramente dependente das necessidades e peculiaridades da pólis. Demais está dizer que essa experiência singular supôs a modificação do princípio de governo do basileús e dos laços de pertencimento entre os homens e os deuses, mutações que produziram sua mais cortante inci390 são na passagem do mito ao lógos. Só no espaço central e na temporalidade da pólis e seu imaginário simbólico poderiam ter sido realizáveis, como efetivamente foram, a participação dos setores médios e o alongamento do elemento popular mediante a reformulação das relações de justiça igual entre semelhantes. Aquilo que alguma vez se chamará de milagre grego foi, por fim o compreendemos, um modo diferente e original de pensar a identidade do Cosmos e do mundo natural e social humano ${ }^{31}$.

A formação da pólis, das póleis, da Grécia arcaica e sua ordenação espacial e temporal não resistiria a uma comparação unilinear com seus antecedentes e influências orientais e naquela trajetória singular os pensadores milésios, com um grau de consciência maior e mais intenso que seus predecessores

\footnotetext{
${ }^{31}$ Raaflaud (2007, pp. 50-57) tenta nos prevenir contra as distorções, exageros e pobres generalizações da pesquisa historiográfica sobre as relações entre os gregos arcaicos e as sociedades orientais, enfatizando o alcance e os limites das analogias, as adaptações e as influências reais.
} 
e contemporâneos, poetas e reformadores, e primeiramente com relação ao pensamento filosófico e ao da medicina, impuseram-se uma exigência peremptória: dotar a razão grega dos recursos conceituais que permitissem canalizar a manifestação racional de uma linguagem e de um início político. A ampliação cosmológica de Anaximandro e a especulação dessa mesma índole empreendida por Thales corresponderam logicamente à experiência social da pólis e suas possibilidades de realização, evidenciando assim as condições lógicas e de possibilidade da homologação da ordem cósmica e a ordem humana por meio da dinâmica da injustiça e da reparação, exequível virtude da igualdade material dos opostos em conflito e da dominação de um que deve reverter na dominação do outro, em um restabelecimento constante do equilíbrio entre a natureza autorregulada e a norma universal (Vlastos, 1970, pp. 73-83; e tb. Jaeger, 1967, p. 159). A uniformidade normativa comum da natureza, verificável tanto na reciprocidade dos componentes elementares quanto nas mútuas correspondências entre a estrutura cosmológica e os valores políticos, apenas estava solicitando uma extensão última e secular: a descrição do mecanismo explicativo interno do todo organizado (Algra, 1999, p. 58), definição científica que será, de idêntico modo, histórica e intelectual. Nessa última retração em e para o interior do Cosmos e da phýsis, entreve-se, em se tratando de uma conclusão e clausura do movimento unitário milésio, a veia genuína da filosofia teórica, a processual e fenomênica captação.

\section{Anaxímenes}

Uma interminável polêmica arrasta o valor, em qualquer caso positivo, da entrada em cena de Anaxímenes, colega e terceiro nome depois de Anaximandro e de Thales, e epílogo especulativo de um modo de pensamento situado e coesivo $^{32}$. Kahn estimou que com Anaxímenes efetuou-se uma

${ }^{32}$ O perfil cronológico e intelectual de Anaxímenes é de difícil determinação: 
espécie de retrocesso das mais avançadas e complexas teses sobre o ápeiron de Anaximandro, seu antecessor imediato (Kahn, 1960, esp. pp. 3-8). Guthrie (2004, pp. 119-120 e ss.), um tempo antes, havia ressaltado os progressos do mais novo pensador relativos à ciência e à religião. Não obstante, levando em conta o mais concentrado escopo da presente análise, caberia dar-se por satisfeito se, em consonância com a interpretação de teoria política que tenho privilegiado, posso adicionalmente prover uma argumentação seletiva e final que remeta a esse terceiro autor. A ela acompanharão, ato contínuo, sumárias conclusões de interpretação geral sobre o pensamento conceitual e político dos filósofos milésios, eixo conjuntivo da análise dos três autores.

Um dos aportes inegáveis de Anaxímenes foi a consolidação do monismo. O dogma monista, enraizado na doutrina de Museu (D. L. I, 3), sofre um giro significativo quando Anaximandro concede à arkhé um nome e um status emi392 nentemente substanciais:

Anaxímenes [...] afirma que o princípio (arkhén) é ar ilimitado (aéra ápeiron), do qual se originam as coisas que chegam a ser, as que chegaram a ser e as que serão, e os deuses e as coisas divinas e as restantes (provêm) dos descendentes (apogónom) dele. Ora, o aspecto do ar e este: quando está disposto do modo mais uniforme possível, não se mostra à vista, mas se mostra com o frio, o calor, a umidade e o movimento. Sempre está em movimento; com efeito, se não se movesse, não mudaria quando muda. Pois ao se condensar e rarefazer, aparece como diferente; pois

sobre ele, ver Cornavaca (2008, pp. 55-56). Diógenes Laércio (D. L. II, 3) refere que escreveu em jônico, numa linguagem simples e isenta de superfluidades, marcando claro contraste com o estilo poético que, segundo Teofrasto, constituíra a força expressiva de seu conterrâneo Anaximandro. Barnes (1987, pp. 37 e 77) limita-se a dizer que Anaxímenes foi "um pálido reflexo" de seu suposto mestre. Para a tradução e organização biográfica e temática dos textos, ver Kirk, Raven e Schofield (1985, pp. 143-62). 
quando se difunde para o mais rarefeito, chega a ser fogo; os ventos são ar que se condensa e do ar se forma a nuvem por compressão, e (ao se condensar) ainda mais de novo, água, e mais [inteiramente] condensado, terra, e no grau máximo de condensação, pedra. De modo que o calor e o frio são os contrários mais importantes da gênese (Hipólito, Refutatio onmium haeresium, I, 7, 1-3, apud Cornavaca, 2008, pp. 56 e 57 [DK 13 A 7], com umas poucas modificações introduzidas por $\mathrm{mim}^{33}$.)

Em vez de pressupor um arkhé-ápeiron diferente e imperceptível, uma qualidade substantivada anterior às demais e igualadas formas da matéria conhecidas pela observação e a experiência, Anaxímenes formulou seu aéra ápeiron, o ar (aér), uma arkhé que, de maneira direta, podia ser mais denso ou mais leve, mais quente ou mais frio, sem por isso deixar de ser a mesma substância que, sob a óptica da génesis, é princípio do ser de todas as coisas que nascerão ${ }^{34}$. Numa estimação justa, Anaxímenes simboliza, mais do que um flagrante recuo ou um dissimulado avanço, uma impressiva virada do logro teórico de Anaximandro. Com relação a esse, o primeiro posicionava-se mais cerca da distinção, que Aristóteles intuiu em todos seus predecessores, entre a substância e seus atributos qualitativos ou acidentais. Mas aquela virada evidenciava, contudo, um mérito maior: a questão conceitual assim formulada estava, ao mesmo tempo, inquirindo o problema pendente da compreensão do processo, isto é, da possibilidade lógica de poder oferecer uma explicação natural acerca da mudança e do desenvolvimento daquelas

\footnotetext{
${ }^{33}$ Para fins de comparação, ver Simplicius, Aristotelis physicorum libros commentaria 24, 26 (DK 13 A 5), Cícero (Academica, II, 37, 118 [DK 13 A 9]) e Guthrie (2004, pp. 124-25).

${ }_{34}$ Estritamente falando, o ar de Anaxímenes, como o ápeiron de Anaximandro, é aquilo do qual todas as coisas recebem seu ser e no qual todas as coisas se dissolverão; ver Aécio, I, 3, 4 (DK 13 B 2).
} 
manifestações consecutivas e concorrentes da vigente ordem cósmica.

Com sólida inferência, argui Guthrie (2004, pp. 122-29):

Esta questão do processo ocupa um lugar preferente em todas as exposições de seu sistema e podemos concluir, com certeza, que ele refletiu precisamente sobre algo que seus predecessores não haviam conseguido abordar de modo satisfatório.

Esse foi, sem sombra de dúvida, seu leitmotiv e problema especial. E nele descansa, por conseguinte, a assunção de que havia um processo natural que reclamava, por si mesmo, uma explicação, um processo tal que havia de demonstrar e que podia ser comprovado constante e regularmente em cada uma das transformações de uma forma ou manifestação da matéria em outra, a saber: o processo (e mecanis394 mo explicativo) da rarefação e da condensação.

A autoria desses princípio e processo não admite contestação. Em Phys. 187a11 e ss. (tb. 184 b15 e ss., e 203 a16 e ss.), Aristóteles diz que há duas tendências entre os filósofos da natureza $^{35}$, os que convertem a substância subjacente em uma única coisa (a água, o ar, o fogo ou um corpo intermédio), fazendo surgir dela a pluralidade de coisas pela rarefação e pela condensação, e os que afirmam que os contrários estavam já no uno, uma mescla da qual as demais coisas se separam (entre os quais cita Empédocles, Anaxágoras e, por razões que respondem mais às lentes analíticas do próprio Aristóteles, Anaximandro). Mas, para completar, em Met. 984a5-7, Aristóteles certifica nominalmente que Anaxímenes, seguido por Diógenes de Apolônia no século posterior, escolheu o ar, antes

\footnotetext{
35 Mediante a denominação de filósofos da natureza, Aristóteles engloba nesse contexto tanto os jônios como os atomistas, assim como a Empédocles e Anaxágoras. No polo oposto, também aos olhos de Aristóteles, situam-se Parmênides e Melisso como proponentes de uma forma de monismo imóvel e radical.
} 
da água, como origem dos corpos simples. Desse modo, com base na evidência textual examinada, resulta claro o reconhecimento da convergência do ar como princípio e da rarefação e condensação como processo no marco da explicação da gênese e da mudança fixado por Anaxímenes ${ }^{36}$.

Pela gênese, mediante rarefação e condensação, Anaxímenes, inspirado provavelmente nos contrários elementares de Anaximandro, sustentou que os primeiros produtos da modificação do ar foram o fogo, a água e a terra, processo que, a partir de sua extensão natural, continuaria idêntico, gerando todo o demais em razão do emparelhamento do quente e seco com a leveza, e do frio e úmido com a densidade. Munido de uma terminologia pós-aristotélica, Plutarco especificou esse desenvolvimento secundário:

[...] como pensava o antigo Anaxímenes, não admitamos na (categoria de) substância o frio ou o quente, senão que (eles são) afeções comuns da matéria que sobrevêm nas mudanças.

Com efeito, afirma que o contraído e condensado de ela (isto é, a matéria) é frio, mas o leve e o frouxo (o denominava assim, com esta palavra [khalapón]), quente (Plutarchus, De primo frigido, 947f1-6; tb. DK 13 B $1^{37}$ ).

Essa novidade do processo reveste particular interesse porque sugere duas ideias ou noções conexas: de modo semelhante

\footnotetext{
${ }^{36}$ Simplício sentiu-se obrigado a corrigir Teofrasto quando esse, mais fiel ao sentido que Aristóteles lhe imprimiu à revisão das doutrinas físicas e metafísicas anteriores, porém desrespeitando o sentido literal das palavras em Met. 984a5, insistiu na autoria exclusiva de Anaxímenes no que diz respeito à referida explicação genética. Sobre a controvérsia, ver Simplicius, Aristotelis physicorum libros commentaria 149, 32, mencionado e comentado em Guthrie (2004, pp. 123-24 e n. 133). Para o método dialético de Aristóteles, consistente na análise e discussão das opiniões generalizadas, isto é, dignas de ser consideradas por sua diferente procedência (comumente admitidas pelos sábios), ver especialmente Top. 100a18-101a4.

${ }^{37}$ Em Plutarchi moralia, v. 5.3, 2. ed., Ed. Hubert, Leipzig: Teubner, 1960 (Thesaurus). Para a tradução do fragmento e um breve comentário, ver Cornavaca (2008, pp. 60-61).
} 
a Anaximandro, concebe-se um movimento eterno (Simplicius, DK 13 A 5) que altera o estado igual ou "uniforme" da matéria original primária (o ar atmosférico) em distintos lugares (o ar e as diversas formas visíveis que adota); e, pela continuidade do mesmo processo de geração de mudanças concatenadas, criam-se a natureza orgânica e a vida em todas as formas deste mundo natural (Cícero, DK 13 A 9) ${ }^{38}$.

Apoiado na inovadora hipótese contida na noção de processo, Anaxímenes vai, com passo firme, além da intuitiva conjectura de Anaximandro. A hipótese implicava, tal como fora tantas vezes observado desde o já clássico livro de Burnet ${ }^{39}$, a introdução de um critério quantitativo para explicar as alterações qualitativas de um mesmo componente primário, verdadeiro mérito e razão fundamental do indicado aprimoramento da premissa monista que urdiu o último pensador milésio. Posto que se reconhece uma primigênia substância material individual, não cabe outra possibilidade que a de considerar 396 quantitativamente todas as diferenças advindas das suas modificações e resultados. Reiterando a aguda apreciação matemática, aclara Guthrie (2004, p. 129):

Ao explicar todas as diferenças qualitativas da matéria por graus diferentes de condensação e rarefação da matéria básica única, Anaxímenes está exigindo já - não podemos dizer procurando - uma explicação quantitativa.

A busca de um mecanismo processual induziu-o, parece, a lançar mão de uma explicação científica e racional

${ }^{38}$ Guthrie (2004, p. 126) acentua uma suposta superioridade de Anaximandro neste ponto: "Provavelmente [Anaxímenes] não tinha para dizer sobre este tema [a origem da natureza orgânica] nada comparável à exposição valente e cheia de imaginação de Anaximandro”. Uma superioridade análoga comprova-se nos detalhes que possuímos de ambos os pensadores relativos a (relação entre) cosmogonia e cosmologia (Guthrie, 2004, pp. 134 e ss).

${ }^{39}$ Burnet, J., Early Greek Philosophy, 4th ed., London, 1930, p. 74, apud Guthrie, 2004, p. 129. 
que consistiu na eleição do ar como arkhé e, consequentemente, como um princípio explicativo capaz de dar conta da multiforme variedade dos corpos físicos. Mas, segundo tem mostrado a racionalidade filosófica constituída pelos outros dois milésios, o lógos grego respirava, em não menor abundância, motivos e motivações que evocavam, ainda em tempos próximos, o clima de cultura e pensamento das cidades jônicas em pleno século VI a.C.(Guthrie, 2004, pp. 129-34).

Anaximandro não evitou e até deixou crescer, em sua teoria, o refluxo de todas aquelas concepções pertencentes ao fundo mítico e popular da religião e das crenças gerais gregas $^{40}$. A suposição de um movimento perpétuo como motor das mudanças resulta, de modo idêntico a Anaximandro, na descrição de um princípio material automovido, o qual, por sua vez, conduz, da maneira em que a iniciou Thales, à definição da causa do movimento desse substrato material, a ideia da alma ou psykhé, isto é, do princípio de uma coisa viva e, por isso, arkhé eterna, imortal e divina. Desde a poesia sagrada (para Guthrie, de cunho órfico) no século VI a.C. a Diógenes de Apolônia, um século depois, a afinidade entre a nossa alma e a divindade foi uma crença preservada que repercutiu, com distintos níveis de sofisticação, em estratos diversos da população. $\mathrm{O}$ ar casava à perfeição com essa ordem de crenças, posto que convidava a associar ou, melhor dizendo, a identificar a alma e o alento que, definitivamente, resumem-se na vida: "Como nossa alma, que é ar, diz [Anaxímenes], mantém-nos unidos, também alento

\footnotetext{
${ }^{40}$ Carentes de precursores filosóficos aos quais recorrer, livres, por assim dizer, de suas impressões e das variações das ideias e preconceitos dos mitos e do povo, os filósofos gregos do período arcaico afirmaram-se, quiçá em maior medida que seus sucessores, num terreno inexplorado e virgem de conceitos. Essas condições de produção histórico-intelectuais equivalem, especula Guthrie, aos pressupostos inconscientes que abrigam todo pensamento: cf. Guthrie, 2004, pp. 121 e 122. Um proceder mais cauto deveria contemplar, no entanto, que essa dimensão não aflora de maneira simples e irrefletida nos processos de elaboração consciente.
} 
(pneúma) e ar abraçam o Universo (kósmon) inteiro" (Aécio, I, 3, 4, apud Cornavaca, 2008, pp. 60-61; e tb. Guthrie, 2004, p. 133; e DK 13 B 2, mais extensamente) ${ }^{41}$. Não cabe dúvida que Anaxímenes estava imbuído desses precedentes poéticos e filosóficos, e, dada essa familiaridade, é legítimo imaginar que, levado pela corrente de sua época, repensasse as concepções religiosas tradicionais e as projetasse no ar, origem primária da vida, de onde em última instância nascem "os deuses e as coisas divinas e as restantes".

Guarde-se que, apesar das ressalvas que possamos interpor ao uso da palavra kósmos no fragmento precitado, nela e na concepção filosófica compreensiva do Universo que ela entranha, não seria inesperado reencontrar a visão de um mundo natural que caracteriza, em essência, um todo organizado, um sistema que se ordena "por simetria de partes, periodicidade de eventos e equilíbrio entre fatores opostos" (Kahn, 1960, p. 230) ${ }^{42}$. Por mais que essa compar398 tilhada visão milésia, ao aparecer na doxografia dedicada a Anaxímenes, não permita mais do que mera conjectura em ausência da confirmação textual que tanto precisaríamos, pode considerar-se, com segura inteligência, que, com esse pensador, estava se encerrando (e se abrindo decisivamente para o futuro) a operação intelectual, a história teórica, da política natural, da protelada naturalização da justiça (transição que Vlastos [1970, p. 83 ad finem] colocou, com estreita e maior prudência, exclusivamente na escrita de Anaximandro). A naturalização da justiça envolveu um processo vasto, depositário de um sedimento cultural, que

\footnotetext{
${ }^{41}$ A autenticidade do fragmento B2 não tem cessado de ser objeto de disputa; ver Cornavaca (2008, pp. 60 e 62), Guthrie (2004, pp. 132-34).

42 É muito provável que nem Anaximandro nem Anaxímenes tenham utilizado a palavra kósmos, ao menos no seu significado definido de ordem do mundo (sentido que foi adquirindo de forma gradual, mas que carregou desde o princípio a noção de ordem) nem, como o seria para a filosofia clássica, significando simplesmente mundo ou universo; ver Guthrie (2004, pp. 114-115). Sobre o termo na filosofia grega arcaica, ver Kahn (1960, pp. 219-30).
} 
só pela clarividência de Anaxímenes alcançou seu ápice na transferência à teoria.

O mundo de Anaxímenes era uma ordem viva. Era, também, uma ordem qualitativamente formada e quantitativamente advinda. Ambos os aspectos, o orgânico e o substancial, confluem na conceituação da phýsis. O domínio da natureza é integral, equitativo, continuado; esse dogma físico prefigura o que, com o passar do tempo, tornar-se-á um problema político: a prioridade do ar impõe-se em todos os elementos e suas derivações; toda mudança é ocasionada, a rigor, pelas variações de um princípio. $\mathrm{O}$ fermento da igualdade democrática age nesse incessante movimento: uma comunidade de iguais, aumentada e multiplicada, brota de uma única materialidade, na qual subsiste sua unidade. O conflito entre o uno e o múltiplo, entre o homogêneo e o heterogêneo, que tanto agitará a filosofia e a teoria política subsequente, era então, de maneira assaz diferente, um problema dos pensadores políticos milésios. A democracia da natureza, sua conflitualidade constitutiva, se assemelha à natureza democrática da política, sua igualdade congênita. A natureza imita a pólis, que um dia completará a natureza.

$* * *$

Talvez o essencial desta interpretação política do pensamento filosófico milésio lance alguma luz sobre a compreensão da própria evolução da filosofia grega e sua teoria da democracia clássica. Desterrados o mito, a magia e o extraordinário pelo império vivo e ubíquo da natureza, exercida a crítica das crenças antropomórficas da religião (Vlastos, 1970, p. 84; Algra, 1999, p. 59), reduzidos e explicados os fatos por suas causas naturais, avaliado o legado dos físicos de Mileto, será preconizado como um imperativo espiritual, num momento derradeiro, reabrirá a brecha por onde se haverá de filtrar a ação e a opinião humanas, a contingência da história 
e da política. Os caminhos da reflexão não terão um curso unívoco e estarão cheios de descompassos e vacilações. Mas isso deve esperar e ser levado a termo por uma indagação centrada na órbita temática da democracia ateniense, a sofística, a filosofia teórica e política clássicas. Por enquanto, a leitura de Anaximandro recém-finalizada concorre à reposição de uma tese historiográfica que, assim esgrimida, ganha uma reconsiderada significação e tem então uma validação alternativa (Vernant, 1965, pp. 105-107).

Os milésios deram vazão a um pensamento racional, preparado, segundo argumentou Vernant (1965, p. 105), pelas condições estruturais e ideológicas da cidade arcaica: "advento da pólis, nascimento da filosofia”. Nesse espaço e nessa temporalidade circunscritas, o movimento intelectual formado por Thales, Anaximandro e Anaxímenes "construiu uma razão, uma primeira forma de racionalidade" (Vernant, 1965, p. 105; grifo no original; e tb. Vernant, 2006, pp. 371-9743). Essa pri400 meira manifestação da razão grega que foi, em seu núcleo mais íntimo, filosófica, revestida pela linguagem da filosofia da natureza, forjada pelos predecessores que Aristóteles denominou fisiólogos, conteve, já que conscientemente o internalizou e elaborou, um vocabulário de conceitos políticos. A história teórica desses pensadores mudou o mito e apartou-se dele, recriou o lógos, concretizou-o numa racionalidade de entidade material e substantiva. Por isso, no que toca à sua mutação genética, a explicação científica excedeu, tanto na cosmogonia como na cosmologia, por densidade conceitual e pelo grau de assimilação da realidade efetiva e formativa das comunidades do período arcaico, as variantes poéticas, os gêneros textuais da épica, as máximas legisladoras e as obras reformadoras. Criou-se e penetrou um modo de pensamento, uma consciência iniciadora e reflexiva, política em sua gênese e sua abordagem natural,

\footnotetext{
${ }^{43}$ Artigo e capítulo de 1957 que, de maneira esclarecedora, concentra-se no pensamento positivo acerca da natureza, nascido nas cidades jônias no século VI a.C., e se intitula "A formação do pensamento positivo na Grécia Arcaica".
} 
política por seu desenvolvimento interno e cultural e por sua versatilidade para expressar a complexidade social, econômica e institucional das comunidades aristocráticas gregas. Nesse pensamento modal, despertava a dinâmica da igualdade e do governo entre cidadãos semelhantes e com poder simétrico. Era, todavia, um movimento unitário e plural que ainda não sabia da forma da constituição e da matéria da democracia...

Em uma mais refinada trama pode ser reposta a fórmula de Vernant que, como resulta evidente, não está ultrapassada, e que tem sido resgatada do rico acervo de teses e interpretações sobre a transição do mito ao lógos:

A razão grega é a que em forma positiva, reflexiva e metódica, permite atuar sobre os homens, não transformar a natureza. Dentro de seus limites, como em suas inovações, é filha da cidade (Vernant, 1965, p. 107).

Em sentido vago, mental e estruturante, à cidade atribuem-se as origens do pensamento. Mas, aprofundada a matização, melhor poderiam os termos da fórmula marchar juntos no mesmo plano abstrato em que foram realmente patenteados: a racionalidade filosófica, porquanto política, razão da pólis. A historía fundida nos moldes da theoría que fez abstração do movimento histórico da génesis e, simultaneamente, impulsionou politicamente um movimento intelectual de composição teórica. A identidade da ordem do mundo natural e da organização do mundo humano é a fórmula integradora do Universo totalizador que a filosofia quis apresar em seu conhecimento. A correspondência mútua, em recíproca justiça, entre a pólis e o pensamento filosófico-político milésio só podia se tornar certa por meios indiretos e interpretativamente apreendidos.

O desenvolvimento do pensamento filosófico arcaico erige-se em peça do desenvolvimento da cidade grega do século VI a.C. A reaproximação e fundamental diferenciação 
do Oriente Próximo e a decisiva recepção e apropriação dos fluxos de conhecimento dali chegados converteram a pólis, considerada uma experiência singular que seguirá um decurso inédito, na formação comunitária preponderante, cimentada num espaço, leis e costumes comuns, articuladora da união diversa de uma economia próspera e de uma ordem potencialmente cada vez mais igualitária. A essa igualdade conatural, na base originária da comunidade política, cabe somar os fatores circunstanciais que fizeram de Mileto e da faixa costeira da Jônia continental e as ilhas o ambiente propício e fértil para o nascimento da universalmente helena razão milésia.

\section{Patricio Tierno}

é professor de Teoria Política no Departamento de Ciência Política da Universidade de São Paulo.

\section{Bibliografia}

ALGRA, K. 1999. The beginnings of cosmology. In: LONG, A. A. (ed.).

The Cambridge Companion to Early Greek Philosophy. New York: Cambridge University Press.

ARISTÓTELES. 1994. Metafísica [Met.], introducción, traducción y notas de Tomás Calvo Martínez. Madrid: Gredos. . 1996. Física [Phys.], texto revisado y traducido por José Luis Calvo

Martínez. Madrid: Consejo Superior de Investigaciones Científicas. 2002. Ética a Nicómaco [EN], edición bilingue e traducción de María Araujo e Julián Marías, introducción e notas de Julián Marías. 8a ed. Madrid: Centro de Estudios Políticos e Constitucionales. ARISTOTLE. 1995. Topics [Top.]. In: The Complete Works of Aristotle. The Revised Oxford Translation, edited by Jonathan Barnes. Sixth Printing, with Corrections. One volume digital edition. Princeton: Princeton University Press. 1995. On the Soul [De An.]. In: The Complete Works of Aristotle. The Revised Oxford Translation, edited by Jonathan Barnes. Sixth Printing, with Corrections. One volume digital edition. Princeton: Princeton University Press.

BALOT, R. K. 2006. Greek political thought. Oxford, UK: Blackwell. 
BARNES, J. 1987. Early Greek philosophy. London: Penguin Books.

CORNAVACA, R. 2008. Filósofos presocráticos. Fragmentos I. Edición bilingue, introducción, traducción y notas de Ramón Cornavaca. Buenos Aires: Losada.

DIELS, H.; KRANZ, W. 1960. Die Fragmente der Vorsokratiker [DK], v. I. Berlin: Weidmannsche.

DIOGENES LAERTIUS. 2013. Lives of eminent philosophers [D. L.]. Edited with introduction by Tiziano Dorandi. Cambridge, UK: Cambridge University Press (Cambridge Classical Texts and Commentaries).

GUTHRIE, W. K. C. 2000. Los filósofos griegos. 2. ed. México: Fondo de Cultura Económica. 2004 [1962]. Historia de la filosofía griega I. Los primeros presocráticos y los pitagóricos. Madrid: Gredos.

HESIOD. 2006. Theogony [Theog.]. Works and Days [WD]. Testimonia, edited and translated by Glenn W. Most. Cambridge, Massachusetts; London, England: Loeb Classical Library, Harvard University Press.

HOMER. 1928 [1934]. The Iliad [Il.], with an English translation by A. T. Murray. Vols. I-II. London: The Loeb Classical Library.

JAEGER, W. 1967. Paideia: los ideales de la cultura griega. México: Fondo de Cultura Económica.

KAHN, C. H. 1960. Anaximander and the origins of Greek cosmology. New York: Columbia University Press.

KIRK, G. S.; RAVEN, J. E.; SCHOFIELD, M. 1985. 2. ed. The presocratic philosophers. Cambridge, UK: Cambridge University Press.

LONG, A. A. 1999. The scope of early Greek philosophy. In: LONG, A.

A. (ed.). The Cambridge Companion to Early Greek Philosophy. New York: Cambridge University Press.

MONDOLFO, R. 2002 [1952]. Breve historia del pensamiento antiguo. Buenos Aires: Losada.

RAAFLAUD, K. A. 2007. Poets, lawgivers, and the beginnings of political reflection. In: ROWE, C.; MALCOLM S. (eds.). The Cambridge history of Greek and Roman political thought. Cambridge: Cambridge University Press.

TIERNO, P. 2014. Formação da pólis e surgimento da democracia na Grécia antiga: história e consciência da Atenas clássica. Hologramática, n. 21, v. 1, pp. 99-119.

VERNANT, J.-P. 1965 [1962]. Los orígenes del pensamiento griego. Buenos Aires: Eudeba. Books. 2006 [1965]. Myth and Thought among the Greeks. New York: Zone 
VLASTOS, G. 1946. Solonian justice. Classical Philology, v. 41, n. 2, pp. 65-83. 1953. Isonomia. The American Journal of Philology, v. 74, n. 4, pp. 337-66. 1970. Equality and justice in early Greek cosmologies. In:

FURLEY, D. J.; ALLEN, R. E. (eds.). Studies in presocratic philosophy. v. I. The beginnings of Philosophy. London: Routledge \& Kegan Paul.

\section{Páginas consultadas na internet}

PERSEUS Digital Library. 1985-2007. Tufts University: <www.perseus.tufts. edu/hopper>

THESAURUS Linguae Graecae. A Digital Library of Greek Literature

[Thesaurus]. 2014. University of California: <www.tlg.uci.edu> 


\section{O PENSAMENTO POLÍTICO DOS FILÓSOFOS MILÉSIOS}

\section{PATRICIO TIERNO}

Resumo: Este artigo pretende examinar o vocabulário político do pensamento milésio, movimento conformado por Thales, Anaximandro e Anaxímenes, autores de uma iniciativa intelectual que se desenvolveu nas circunstâncias históricas imperantes em Jônia durante o século VI a.C. No âmbito da pólis arcaica, esses pensadores formularam uma filosofia da natureza que, em diálogo e tensão com a mitologia tradicional e a religião antropomórfica, estabeleceu as bases de uma racionalidade filosófica e política concreta, a qual se manifestou numa linguagem conceitual e expressou a experiência singular da cidade grega antiga e as condições de sua evolução social transformadora.

Palavras-chave: Pensamento Filosófico; Razão; Pólis; Mileto; Natureza; Política.

\section{THE POLITICAL THOUGHT OF MILESIAN PHILOSOPHERS}

Abstract: This paper aims at investigating the political vocabulary of the Milesian thought, that is, the intellectual movement composed by Thales, Anaximander and Anaximenes and developed in the special circumstances of sixth-century BC Ionia. In the context of archaic polis, these thinkers presented a philosophy of nature that established the basis of a concrete philosophical and political rationality, which was manifested in a conceptual language and expressed the singular experience of the ancient Greek city and the conditions of its social and mutable evolution, in dialogue and tension with the traditional mythology and anthropomorphic religion. Keywords: Philosophical Thought; Reason; Polis; Miletus; Nature; Politics.

Recebido: $17 / 05 / 2016$

Aprovado: 21/02/2017 